トピック

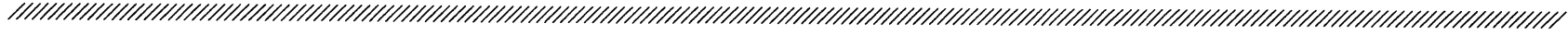

\title{
マレーシアで発生した豚のニパウイルス感染症
}

\author{
山川 睦', 筒井俊之 ${ }^{2}$ \\ 1農林水産省家畜衛生試験場海外病研究部 \\ 2農林水産省畜産局衛生課国際衛生対策室

\section{The Outbreak of a New Emerging Disease, Nipah Virus Infection in Malaysia}

\author{
Makoto YAMAKAWA and Toshiyuki TSUTSUI
}

1998年，マレーシアにおいて宿主域を越えて感染する 新しいパラミクソウイルスが出現し, 家畜衛生のみなら ず公衆衛生上も大きな問題として取り上げられた。1999 年11月, 台湾で開催された第21回 OIE アジア・極東及び オセアニア地域委員会で得られた豪州家畜衛生研究所及 び米国疾病管理・予防センター (CDC) の情報をもと に, 動物 (特に豚) のニパウイルス感染症に関してこれ までに得られた知見の概要を紹介する。

\section{1 発生疫学}

マレーシア半島において，1998年10月から始まった新 たな豚及び人の疾病であるニパウイルス感染症は, 1999 年 5 月に終息するまで, 105 名の死者と 90 万頭以上の豚の 殺処分をもたらした。これまで，マレーシアにおいては， 同, 人及び犬がこの疾病に感染したことが知られている が, 馬や猫などの他の動物についても感染豚と接触した 場合に感染が成立したと考えられている。人でのウイル 不性脳炎が問題となっていた時期に実施された人への感 染源を特定するための疫学調査の結果, 人への感染は主 に豚, 特に発症胀との直接接触であることが明らかとな った。豚以外の動物が感染源となることは完全に否定し きれないが，大規模な豚の殺処分の実施以降に新たな感 染が起こっていないことも, 豚が感染源として重要な役 割を果たしていることを示している。

疫学調査の結果, 二パウイルス感染症の初発地域はイ

連絡先： $7187-0022$ 東京都小平市上水本町6-20-1 山川 睦 農林水産省家畜衛生試験場 海外病研究部 診断研究室

Tel : 042-321-1441 Fax:042-325-5122

e-mail: yamato@ed.affrc.go.jp
ポー地域であることが示唆されているが, 初発生の感染 源や豚への感染ルートは未だ不明である。また, 自然界 のレゼルボアも不明であるが, 流行地域の野生動物の調 査の結果, Pteropus 属のフルーツコウモリに中和抗体が 確認されている。豪州におけるへンドラウイルス感染症 も同種のコウモリの関与が疑われていることから, 現在, 米国の CDC がウイルス分離と PCR 検査を用いた調査 を実施しており，今後これらコウモリの役割についてさ らなる研究が行われる予定である。

\section{2 伝播様式}

ニパウイルス感染症は, マレーシア半島中部に位置す るPerak 州を初発地域とし, その後感染豚の移動によっ て南部の Negeri Semblian 州及び Selangor 州に広がっ たと考えられている。マレーシア半島においては従来か ら豚の取り引きが活発に行われているが, 特に, 初発地 域の Perak 州でニパウイルス感染症が流行した時期に 多くの豚が他の地域に廉価で販売された結果, 潜伏感染 豚を介して他地域の農場に広がっていったと考えられる。 これは, 感染農場の近隣農場であっても, 感染したおそ れがある豚を導入していない農場は，その後のサーベイ ランスによっても感染豚が摘発されなかったことからも 明らかである。また, 感染のおそれのある農場から肥育 用豚を導入した農家が直ちにすべての肥育豚を淘汰した 場合, その後の検查においてその農場から抗体陽性豚が 摘発されていないが, 污染地域から繁殖豚を導入した農 場からは抗体陽性豚が摘発されていることもサーベイラ ンスで明らかとなっている。これは，一般的に肥育豚は 繁殖豚と別棟で飼養されており, 肥育豚から繁殖豚に接 触する機会がなかったことによるものと考えられている。 
集落内の農場間の伝播要因としては, 種豚の精夜, 犬 猫の機械的伝搬が疑われている。また, 農場内での伝播 は, 尿, 鼻汁等を介した感染胀からの直接伝搬, 注射針 などの診療用具を介した伝搬，人工授精を介した伝搬な ぞが原因と考元られている。豪州の家畜衛生研究所にお ける豚への感染実験の結果, 豚は経口及び非経口感染が 成立し, 感染豚は鼻口からウイルスを排出することが証 明されている。この実験においては, 直接接触のない豚 も感染し，14日目に中和抗体が検出されている。

\section{3 豚以外の動物における感染}

（1）犬及び猫ニパウイルス感染症が豚に流行した時期に 行われた流行地域である Bukit Pelanduk 及び Sepang における犬の抗体検査の結果は，それぞれ $55 \%(36 / 66)$ ， $23 \%$ (6/26)であった。初発生から 3 ケ経過した本年5月 中旬に, 両地域において再度犬の血清学的サーベイラン スが行われた。血液サンプルは発生地域を中心として8 $\mathrm{km}$ 以内の地域, $8 \sim 15 \mathrm{~km}$ の地域及び $15 \mathrm{~km}$ 以上の地域 に区分して,88頭の野犬と161頭のペット犬から採取され た。これらの血清を用いた抗体検査の結果, $8 \mathrm{~km}$ 以内の 地域の 3 頭 (2.8\%)及び $8 \sim 15 \mathrm{~km}$ の地域の1頭(1.3\%) が抗体陽性であった。15km 以上の地域においては抗体 陽性犬は認められなかったこと及び高污染地域近郊の犬 の抗体陽性率が極めて低かったことから, 犬の間の感染 は起こっていないこと及び犬の感染は豚での感染が高率 に起こっている地域のみに起こることが強く示唆された。 2 頭の猫の実験感染が豪州家畜衛生研究所で行われ， 1 頭は呼吸器症状を示し頉死の状況に陥ったが, 他の 1 頭 は発熱後回復した。2 頭の猫の尿からニパウイルスが分 離された。流行後に Perak 州の犬396頭及び猫114頭の血 液サンプルが豪州家畜衛生研究所に送付され, 中和検査 が行われたが全て陰性であった。

(2) 馬

本年 3 月及び4月に 3,200 以上の血清サンプルが競走馬, 競技用馬から採取され, 豪州家畜衛生研究所で中和検査 及びELISA 検査が行われた。その結果47頭が飼養され ているポロクラブの 2 頭の馬のみが抗体陽性であった。 当該陽性馬は臨床症状を示しておらず，剖検においても 病変は確認されなかった。サンプルが採取され, 豪州家 畜衛生研究所に送付されたが, 免疫組織化学的検査及び PCR 検査においても陰性であり, ウイルスも分離されな かった。疫学調査によれば,この 2 頭の馬は一時的に養 豚農家に係留されており，この時点で暴露されたと考え られている。これらのことから, 馬から馬への感染は起 こっていなかったとものと考えられている。

（3）その他の動物
流行時期である本年3月に Bukit Pelanduk 及びSepang において,多くの動物の血液サンプルが採取され米 国 CDC で検査が行われた結果, 山羊 $1.5 \%(1 / 65)$, 猫6.4 $\%(1 / 24)$, 鳥 $6.4 \%(7 / 109)$, 蹯歯類 $0.4 \%(1 / 278)$ が抗体 陽性であった。しかしながら,これらの動物の間でニパ ウイルス感染症がひろがっているという証拠は認められ ていない。現在, ウイルス分離及び PCR 検查が引き続き 行われている。

\section{4 ニパウイルスの性状}

Negeri Sembilan 州の Sungai Nipah 村の脳炎患者か ら分離されたウイルスは，CDCによる詳細な研究によ り，パラミクソウイルス科に属し，オーストラリアで分 離されたヘンドラウイルス（1994年に発生した競走馬及 び人の重篤な呼吸器病の原因ウイルス）と血清学的に交 差することが確認された。そのため当初へンドラ様ウイ ルス（Hendra-like virus）と呼ばれていたが，遺伝子解 析の結果，ヘンドラウイルスとは異なるウイルスである ことが明らかとなり, 分離された地名にちなんでニパウ イルスと命名された。また, 塩基配列をもとに行った分 子系統樹解析の結果から, ニパウイルスはヘンドラウイ ルスとともにモルビリウイルス属（犬ジステンパーウイ ルスや牛疫ウイルス, 小反势獣疫ウイルス等が含まれる) に近縁であるが, パラミクソウイルス科の既存のどの属 にも分類し得ないことが判明した。現在, 両ウイルスか ら構成される新しい属をもうけることが提唱されている が,まだ属名は決まっていない。ニパウイルスをVero 細 胞等の培養細胞に接種すると, 特徵的な $\mathrm{CPE}$ (細胞変性 効果)を見ることができる。すなわち, シンシチウム(細 胞融合による合胞体) が出現し, やがて多核巨細胞を形 成する。ウイルス粒子の電子顕微鏡観察では, パラミク ソウイルス特有の矢筈 (herringbone) 型のヌクレオカプ シド構造（長さ約 $1.6 \mathrm{~nm}$, 平均直径 $21 \mathrm{~nm}$ ) が認められ る。ウイルス粒子のサイズは $100 \mathrm{~nm}$ 以下であるが, 多形 性を示す粒子のサイズにはばらつきがある（平均500 $\mathrm{nm}$ )。エンベロープ上には, 長さ約 $10 \mathrm{~nm}$ の突起 (projection) が散在している。異なる動物種 (人, 豚, 犬) から 分離されたニパウイルスの塩基配列は，今まで調べられ た限りでは，全く同じである。

\section{5 臨床症状}

一般に死亡率は低いが ( 5 \%程度), 感染率は高い（養 豚場によっては $95 \%$ にぶことがある)。感染豚の多数は 症状を示さない。7～14日の潜伏期を経て発症する呼吸 器あるいは神経症状を伴う急性熱性疾患であるといえる。 呼吸器症状としては, 呼吸数増加, 開口呼吸, 強制呼吸, 
激しい発咳等がみられる。神経症状としては，頭を押し つける, 柵を啮むというような症状の他に, 振戦, テタ ニー性痙攣, 筋肉㧛縮等が観察される。年齢によって症 状が若干異なり, 成胀では神経症状が, 食用豚では呼吸 器症状が強く現れる傾向にある。繁殖雌豚, 種豚では時 に無症状のまま，あるいは鼻孔からの出血を伴って死に 至ることがある。また妊張豚が感染した場合には，流産 が認められることがある。

\section{6 病 理}

感染豚には顕著な肺及び脳病変が観察される。肺水腫, 点状及び斑状出血等の種々の程度の肺病変が認められる。 広範囲にわたる出血と肺血管内皮細胞の巨細胞形成を主 徵とする間質性肺炎が特徵である。一般的に線維素様壊 死を伴う血管炎, 出血, 血栓症の原因となる単核細胞の 浸潤が肺，腎臓，脳組織にみられる。脳には，これら以 外にも非化膿性髄膜炎, 神経膠症が認められる。血管内 皮細胞には大量のウイルス抗原が検出されるが，特に肺 において著明である。上部気道管腔内の細胞片や洷出物 にウイルス抗原がみられることから，気道を経てウイル スが排出され，伝播していく可能性が示唆されている。

\section{7 診 断}

ニパウイルスは豚だけでなく，人を含むその他の動物 にとっても危険な病原体であるため, ウイルス分離, PCR, ウイルス中和試験による確定診断, 診断用 ELISA 抗原の調整, 動物接種試験等, 生ウイルスを使用するす べての操作は，バイオセーフティレベル 4 (BSL4) の施 設内で熟練したスタッフによって実施されなければなら ない。ニパウイルス感染が疑われる地域での獣医師の活 動 (サンプリング等), 確定診断のために BSL4施設に持 ち込むまでの（通常実験室での）サンプル処理法につい ては, 安全指針が作られている。

(1) 血清学的診断

もっとも確実な血清診断法は, 言うまでもなくウイル ス中和試験である。上記のとおり, 東南アジア地区で採 取された血清サンプルを用いた中和試験は，豪州家畜衛 生研究所の BSL4施設内で行われている。ニパウイルス 感染症発生当初は，ヘンドラウイルスを抗原とする間接 ELISA 法が採用されていた(ニパウイルスと交差反応性 を示すため）が，現在ではニパウイルスそのものを抗原 とする方法に切り替えられている。被検血清は感染性を 不活化するため, 界面活性剤を加えて加熱処理した後に 用いられている。この ELISA 法では, 特異性が高い分, 非特異反応がみられることも多く，中和試験による確定 診断が必要な場合がある。したがって, 現行の ELISA 法
は, サーベイランス計画の中で污染農場を摘発するため のスクリーニングテストとして用いるには最も有効な方 法であるが，二パウイルス感染を示す決定的診断方法と はならない。また, ニパウイルス感染とヘンドラウイル ス感染の鑑別も困難である。

（2）免疫組織化学染色

肺や脳等のホルマリン固定感染組織内のウイルス抗原 をイムノペルオキシダーゼ検出系を用いた発色によって 検出する方法で, ウイルス感染を直接証明する上で最も 有効である。固定した組織を用いるため, 病理組織検査 が可能な実験室であればどこでも採用できる安全な診断 法であり，二パウイルス感染症の診断において最も推奨 される。サンプリングには急性期にある動物を選ぶのが 理想的であり, 可能な限り多くの動物（特に豚の場合） を検査する必要がある。

(3) RT-PCR 法

RT-PCR (reverse transcriptase polymerase chain reaction) 法は, 必要機器・試薬, ノウハウを持つ実験室 において, 上記の方法に代わるウイルス検出法として用 いることができる。すでに核タンパク質遺伝子(Ngene) を標的としたニパウイルス特異的プライマーが設計され ている。感度, 迅速性・特異性に優れている反面, サン プル採取・処理過程におけるコンタミネーションによる 偽陽性（誤診）の問題がつきまとうのが難点である。ま た, PCR の材料として感染ウイルスを含む新鮮組織を用 いる関係上, 術者への感染が危惧されることから, BSL4 施設以外では実施すべきではない。

（4）ウイルス分離

マレーシアにおける豚のニパウイルス感染は, Vero 細胞等を用いたウイルス分離によって確認されたが， ウ イルス分離操作は, 実験室スタッフにとって非常に危険 な作業を伴う。二パウイルス感染症の野外調査を行うよ うな場合, 当然のことながらウイルス分離を主体とすべ きではない。

\section{8 その他}

これまで, 本病が脉肉の摂食を介して人に感染するこ とは知られておらず, 米国及び豪州の専門家も食品衛生 上の問題として扱うことには否定的であったが, マレー シアにおいては本病の発生に伴って豚肉の消費が低下し, 多大の損害を受けたということであった。マレーシアで のニパウイルス感染症の発生は一応の終息をみたが, 今 後, 自然宿主の特定, 豚における持続感染の有無, 豚以 外の動物の感染源としての可能性等についてさらなる調 査・研究を行っていく必要がある。オーストラリア側の 意見によれば，上記のようにニパウイルスを扱う試験研 
究にはBSL4の施設が必要なため, 研究の推進に制約が

生じているとのことであった。 